\title{
Herpes Simplex Virus 2 IgG Antibody Measurement
}

National Cancer Institute

\section{Source}

National Cancer Institute. Herpes Simplex Virus 2 Ig G Antibody Measurement. NCI

Thesaurus. Code C96667.

The determination of the amount of Herpes Simplex virus 2 Ig G antibody present in a sample. 